\title{
Extraction of Copper from Copper-Bearing Materials by Sulfation Roasting with $\mathrm{SO}_{2}-\mathrm{O}_{2}$ Gas
}

\author{
XINGBANG WAN (i), ${ }^{1,4}$ JUNJIE SHI $\mathbb{1}^{1,2,3,5}$ PEKKA TASKINEN @i], ${ }^{1,6}$ \\ and ARI JOKILAAKSO (1) ${ }^{1,7}$
}

\begin{abstract}
1.-Department of Chemical and Metallurgical Engineering, School of Chemical Engineering, Aalto University, PO Box 16100, 00076 Espoo, Finland. 2.-School of Metallurgy, Northeastern University, 110819 Shenyang, China. 3.-Key Laboratory for Ecological Metallurgy of Multimetallic Mineral (Ministry of Education), Northeastern University, $110819 \quad$ Shenyang, China. 4.-e-mail: xingbang.wan@aalto.fi. 5.—e-mail: junjieshi@126.com. 6.—e-mail: pekka.taskinen@aalto.fi. 7.—e-mail: ari.jokilaakso@ aalto.fi
\end{abstract}

Recycling metals from secondary materials and more complex ores has recently been attracting more attention, creating a need for more precise separation methods of different elements. This study proposed a sulfation-roasting method and designed thermodynamic conditions to selectively facilitate the formation of copper sulfate while separating iron as oxide. The roasting behaviors for chalcopyrite, copper slag, and pure copper compounds were investigated in a $0.5 \% \quad \mathrm{SO}_{2}-0.5 \% \quad \mathrm{O}_{2}-99 \%$ Ar atmosphere at $600^{\circ} \mathrm{C}$. X-ray fluorescence spectroscopy, x-ray diffractometry, scanning electron microscopy, and energy dispersive x-ray spectrometry were used to characterize the raw materials and roasting products. The proposed methodology was confirmed for a complete separation of $\mathrm{Cu}$ from $\mathrm{Fe}$, and, further, the sulfation-roasting mechanism of chalcopyrite was confirmed by thermodynamic calculations and experimental observations. These will provide a theoretical basis for copper recycling from both complex primary and secondary copper-bearing materials.

\section{INTRODUCTION}

Copper is an important nonferrous metal that has been used for thousands of years due to its versatile and highly applicable properties. ${ }^{1}$ The increasing demand for copper and depletion of high-grade ores have prompted intensive investigation on metal recovery from low-grade ores and secondary copperbearing resources. ${ }^{2}$ For low-grade ores or secondary resources, such as copper slag and e-waste (waste of electronics and electrical equipment), utilization is challenging because of the complexity of their composition. A typical composition of copper slag is as follows: $30-40 \% \mathrm{Fe}, 35-40 \% \mathrm{SiO}_{2}, \leq 10 \% \mathrm{Al}_{2} \mathrm{O}_{3}$, $\leq$ $10 \% \mathrm{CaO}$, and $0.5-2.1 \% \mathrm{Cu}^{3}$ Regarding e-waste, in

(Received April 4, 2020; accepted July 22, 2020;

published online August 11, 2020) addition to the common metals, such as $\mathrm{Fe}, \mathrm{Cu}, \mathrm{Al}$, and $\mathrm{Ni}$, it also contains trace amounts of precious, rare and rare earth elements $\mathrm{Au}, \mathrm{Ag}, \mathrm{Pt}, \mathrm{Pd}, \mathrm{Cd}, \mathrm{Se}$, As, Co, Te, Ta, Ru, Ge, Ga, Rh, Sn, Pb, and $\mathrm{Bi}$ ), which make recycling quite demanding. ${ }^{4,5}$ With increased public attention on environmental protection, studies of cleaner and truly circular approaches to produce copper from complex copper-bearing resources are urgently needed.

It is well known that copper has commonly been extracted using pyrometallurgical and hydrometallurgical processes. ${ }^{6,7}$ In pyrometallurgical processing routes, froth flotation before smelting is applied to pretreat and obtain the desired grade of copper concentrates. However, for low-grade ores and complex copper-bearing materials, it is often unfeasible to produce copper concentrates with the target assay for smelting. ${ }^{8}$ What is even more relevant is that uncontrolled off-gas and fugitive emissions from pyrometallurgical plants may cause serious pollution. 
Hydrometallurgical processes, on the other hand, based on the interactions of minerals with chemicals in an aqueous solution, are appropriate and alternative methods for metal extraction/recovery. However, direct leaching of chalcopyrite concentrates presents major problems concerning the slow dissolution kinetics of chalcopyrite as well as issues of precipitation and the disposal of large amounts of iron residues. ${ }^{9-11}$ Although some approaches have been successfully applied in chalcopyrite leaching, ${ }^{12-14}$ more research is needed to deal with complex copper-bearing materials.

Considering the abovementioned shortcomings of pyro- and hydrometallurgical methods, studies have been undertaken by some researchers to combine such processes for treating lithium battery waste by nitration roasting, ${ }^{15}$ sulfation roasting, ${ }^{16}$ reduction roasting with carbon, ${ }^{17}$ and vacuum evaporation, ${ }^{18}$ followed by leaching. Zheng ${ }^{19}$ applied sulfation roasting combined with a flotation approach to recycle zinc from smelting slag, and the total zinc recovery reached $80.78 \%$. In previous research,,$^{20}$ it was also proved that vanadium can be effectively recycled from slags by direct roasting at $850^{\circ} \mathrm{C}$ and soda leaching, attaining a leaching yield of vanadium of $90 \%$. Roasting is a simple and efficient method for treating complex copper-bearing materials and provides advantages in terms of economic efficiency and environmental friendliness when combined with hydrometallurgical processes. Among the roasting techniques, sulfation roasting in lean $\mathrm{SO}_{2}$ gas is characterized by the precise and selective extraction of valuable metals, such as $\mathrm{Cu}$, $\mathrm{Ni}, \mathrm{Co}$, and $\mathrm{Mn}$, and has been widely used in the past for primary and secondary materials, including pyrite, nickel, and copper concentrates as well as lepidolite. ${ }^{21,22}$

According to the literature on copper concentrate roasting ${ }^{23-25}$ and predominance area diagram studies, ${ }^{26-28}$ it is possible to select the stable forms of sulfides, sulfates, oxides, or even metallic copper in the system with a suitable combination of temperature and atmosphere. ${ }^{29}$ This feature has been the basis of several studies on copper extraction and recovery. ${ }^{30-35}$ For the majority of copper-bearing materials where iron is the major metal, copper and iron can be converted to copper sulfate and iron oxide by controlling the atmosphere. ${ }^{36}$ The products can be effectively separated in water leaching and by filtering the non-soluble iron oxide from the copper sulfate solution. ${ }^{29}$ The salt can then be further crystallized or recovered as metal, e.g., in electrowinning.

Nowadays, copper extraction and recycling processes need to be more adaptable because the raw materials are becoming more complex and have lower copper contents. Recently, some studies have been published on the sulfation roasting phenomena in copper recycling from industrial slags in a laboratory-scale furnace. ${ }^{33,37,38}$ Besides slags, sulfation-roasting techniques have also been applied by roasting a smelting $\operatorname{slag}^{31}$ as well as flotation tailings ${ }^{8}$ together with pyrite. However, the roasting characteristics between different copper-bearing materials have not been compared before, and few studies have been carried out on the sulfation roasting mechanism itself. Furthermore, a detailed thermodynamic analysis and the reaction mechanism for the sulfation-roasting processes of different types of complex copper-bearing materials are still required. The reaction mechanism may be utilized for optimizing the operational conditions of roasting.

The general aims of this study were associated with the development of a preliminary assessment of this type of reaction system in order to produce $\mathrm{CuSO}_{4}$ and $\mathrm{Fe}_{2} \mathrm{O}_{3}$ selectively from different copperand iron-bearing materials, without any sulfation promoters. The operational conditions were defined by a thermodynamic evaluation of the $\mathrm{Cu}-\mathrm{Fe}-\mathrm{O}-\mathrm{S}$ system in a $\mathrm{SO}_{2}-\mathrm{O}_{2}$ - $\mathrm{Ar}$ atmosphere. Moreover, the sulfation-roasting mechanism of chalcopyrite was established in this study, regarding both thermodynamic and experimental aspects. The novelty of this process is not only an alternative method for handing various copper-bearing materials, but also an option for recovering other ores and residues, such as rare earth slags. ${ }^{39}$

\section{EXPERIMENTAL}

\section{Materials}

The raw materials for the experiments in this study were industrial chalcopyritic copper concentrate and a copper smelting slag. Pure $\mathrm{CuS}, \mathrm{CuO}$, and $\mathrm{Fe}_{2} \mathrm{O}_{3}$ powders (99.999\%; Alfa Aesar, Kandel, Germany) were also used as reference materials. The chalcopyritic concentrate and industrial slag were provided by the Boliden Harjavalta smelter, Finland, and both were well ground to powders before the experiments. The chemical composition of the concentrate was analyzed by $\mathrm{x}$-ray fluorescence (XRF) spectrometry (Malvern Panalytical, Almelo, the Netherlands) and that of the slag by inductively coupled plasma-optical emission spectroscopy (ICPOES) (PerkinElmer Optima 7100 DV, USA). The relative uncertainty of the XRF data was better that $\pm 5 \%$ and that of the ICP-OES better than \pm $3 \%$, and the results are shown below in Tables I and II

\section{Apparatus}

The experimental apparatus used is shown in Fig. 1. It comprised a horizontal tube furnace equipped with four silicon carbide ( $\mathrm{SiC}$ ) heating elements. The temperature of the furnace was set by a Eurotherm PID controller. In the hot zone of the furnace, a calibrated S-type thermocouple (JohnsonMatthey Noble Metals, UK) was used to constantly monitor the temperature, and the temperature data were logged with LabVIEW software. The 
Table I. Chemical composition of the chalcopyritic concentrate (wt.\%)

\begin{tabular}{|c|c|c|c|c|c|c|c|c|c|c|c|}
\hline $\mathbf{C u}$ & $\mathbf{F e}$ & $\mathbf{S}$ & $\mathbf{Z n}$ & As & $\mathbf{B i}$ & Ag & $\mathbf{A u}$ & $\mathbf{C a}$ & $\mathrm{Cr}$ & $\mathbf{P b}$ & $\mathbf{S i O}_{2}$ \\
\hline 29.2 & 27.0 & 34.5 & 4.3 & 0.05 & 0.001 & $200^{\mathrm{a}}$ & $4^{\mathrm{a}}$ & 0.07 & 0.01 & 0.1 & 2.5 \\
\hline
\end{tabular}

${ }^{\mathrm{a}} \mathrm{In} \mathrm{ppm}$.

Table II. Chemical composition of the smelting slag (wt.\%)

\begin{tabular}{|c|c|c|c|c|c|c|c|c|c|c|c|c|c|c|c|c|}
\hline $\mathrm{Cu}$ & $\mathbf{F e}$ & $\mathbf{S}$ & $\mathbf{K}$ & $\mathbf{C a}$ & $\mathrm{Cr}$ & Mg & Co & $\mathbf{N i}$ & $\mathbf{N a}$ & $\mathbf{Z n}$ & As & $\mathbf{S b}$ & $\mathbf{P b}$ & $\mathbf{B i}$ & $\mathbf{A l}$ & $\mathrm{SiO}_{2}$ \\
\hline 1.2 & 37.9 & 0.4 & 0.9 & 0.8 & 0.03 & 1.2 & 0.06 & 0.05 & 0.41 & 1.8 & 0.1 & 0.1 & 0.3 & $<0.02$ & 2.3 & 31.7 \\
\hline
\end{tabular}

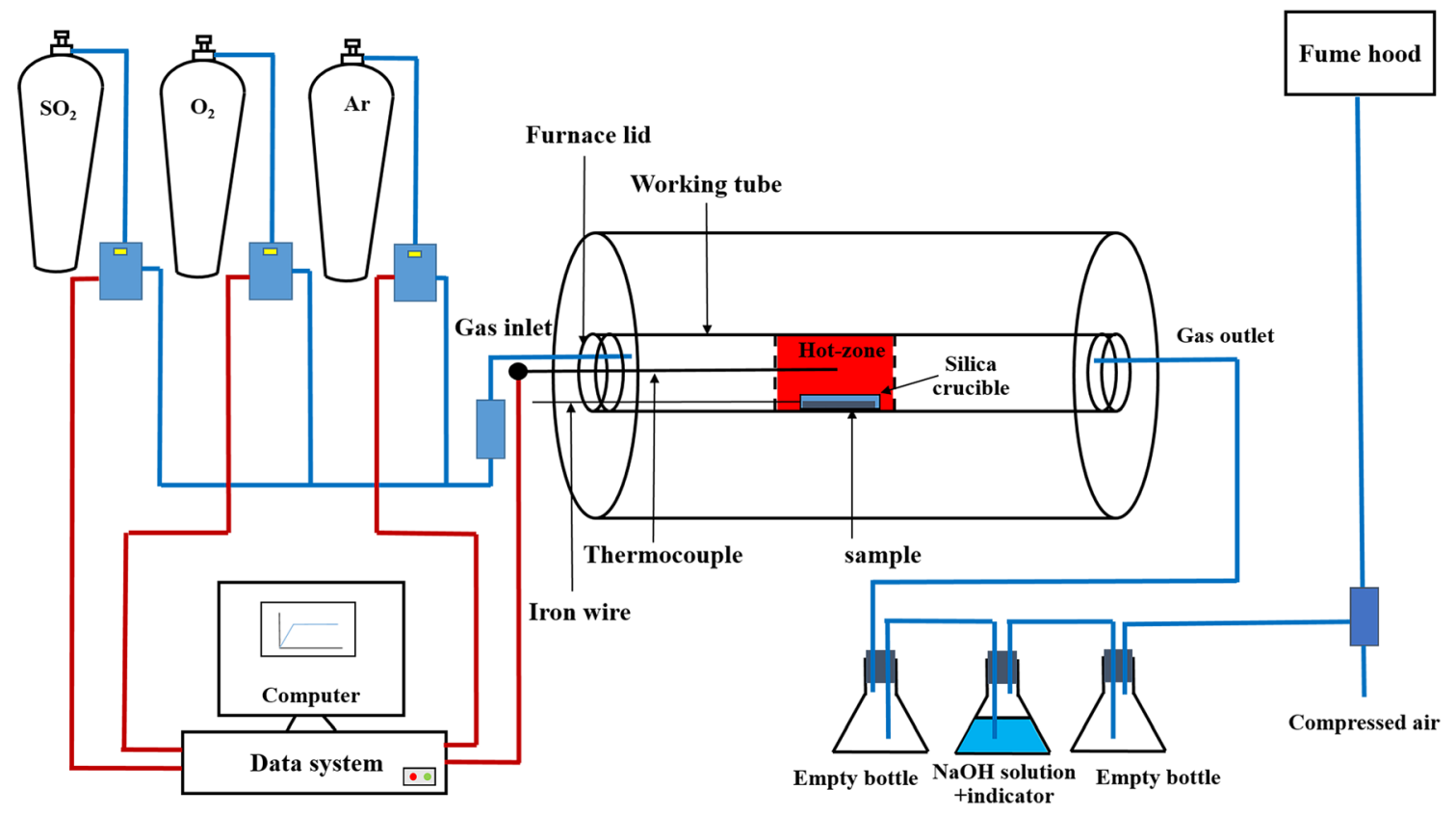

Fig. 1. Roasting experimental schematic and the control and data-logging devices.

experimental atmosphere was achieved by mixing $\mathrm{SO}_{2}(99.99 \%), \mathrm{O}_{2}(99.99 \%)$, and $\mathrm{Ar}$ gases $(99.999 \%)$ (AGA-Linde, Finland). The flow rates were controlled using digital mass flow meters (Aalborg, USA) and the off-gas was absorbed by $\mathrm{NaOH}$ solution with BTS as a pH indicator (bromothymol blue, $\mathrm{C}_{27} \mathrm{H}_{28} \mathrm{Br}_{2} \mathrm{O}_{5} \mathrm{~S}$; Sigma-Aldrich, USA) to completely remove the $\mathrm{SO}_{2}$ before venting to a fume hood. Rectangular-shaped silica boats $(130 \mathrm{~mm}$ long, $30 \mathrm{~mm}$ wide, $9.5 \mathrm{~mm}$ high, $3.5 \mathrm{~mm}$ thick) were used in the study to contain the reactants.

\section{Procedure}

During the experiments, the boat containing the sample was slowly pushed into the hot zone in flowing argon, and then the head of the furnace was sealed. After the temperature of the hot zone reached the target value of $600^{\circ} \mathrm{C}$, the gas with a total flow rate of $1000 \mathrm{~mL} / \mathrm{min}$ ( $0.5 \mathrm{vol} . \% \mathrm{SO}_{2}-$ 0.5 vol. $\% \mathrm{O}_{2}-99$ vol.\% $\mathrm{Ar}$ ) was introduced to generate the reaction atmosphere of the system. Then, after a preset roasting time, the boat was pulled out from the hot zone to the cooled head and the material was cooled in argon atmosphere before being removed from the work tube.

To study the copper and iron separation and the reaction mechanisms of the sulfation-roasting process, a series of experiments were conducted. Copper smelting slag and chalcopyritic copper concentrate were roasted for $8 \mathrm{~h}$ and $24 \mathrm{~h}$, respectively, to verify the roasting behavior of residual copper in smelting slag. Pure $\mathrm{CuS}, \mathrm{CuO}$, and $\mathrm{Fe}_{2} \mathrm{O}_{3}$ powders were also roasted for $8 \mathrm{~h}$ in the same atmosphere to verify the roasting mechanism. 


\section{Analysis}

The roasted samples were characterized by x-ray diffraction (XRD; PANalytical X'Pert Pro Powder; Almelo, the Netherlands) using $\mathrm{Co}_{\alpha}$ radiation at a scan rate of $5 \% \mathrm{~min}$ from $10^{\circ}$ to $90^{\circ}$ (acceleration voltage $40 \mathrm{kV}$, current $40 \mathrm{~mA}$ ). The roasted samples were mounted in epoxy resin, polished, and coated with carbon, and then analyzed with a scanning electron microscope (SEM; Tescan, Brno, Czech Republic) and an UltraDry silicon drift energy dispersive x-ray spectrometer (EDS; Thermo Fisher Scientific, Waltham, MA, USA). The standards used were from Astimex (Ontario, Canada) and data analysis was carried out with NSS microanalysis software.

\section{THERMODYNAMICS}

The proper reaction atmosphere and temperature were mapped for recycling copper from copper- and iron-bearing materials in the form of a copper sulfate and iron oxide mixture. Thermodynamic calculations were carried out using the commercial software HSC Chemistry, due to its advantageous features of complex, solid-state reaction predictions in oxide-sulfide systems. ${ }^{40}$ HSC Chemistry $9.0^{41}$ was employed to calculate the equilibrium characteristics shown in Fig. 2.

Figure $2 \mathrm{a}$ shows a constrained Ellingham diagram at a fixed sulfur dioxide partial pressure $\left(P_{\mathrm{SO} 2}=0.01 \mathrm{~atm}\right)$ for the sulfation process of selected metals that may exist in secondary copper-bearing materials. As shown in the diagram, the conversion of ferric oxide to ferrous sulfate
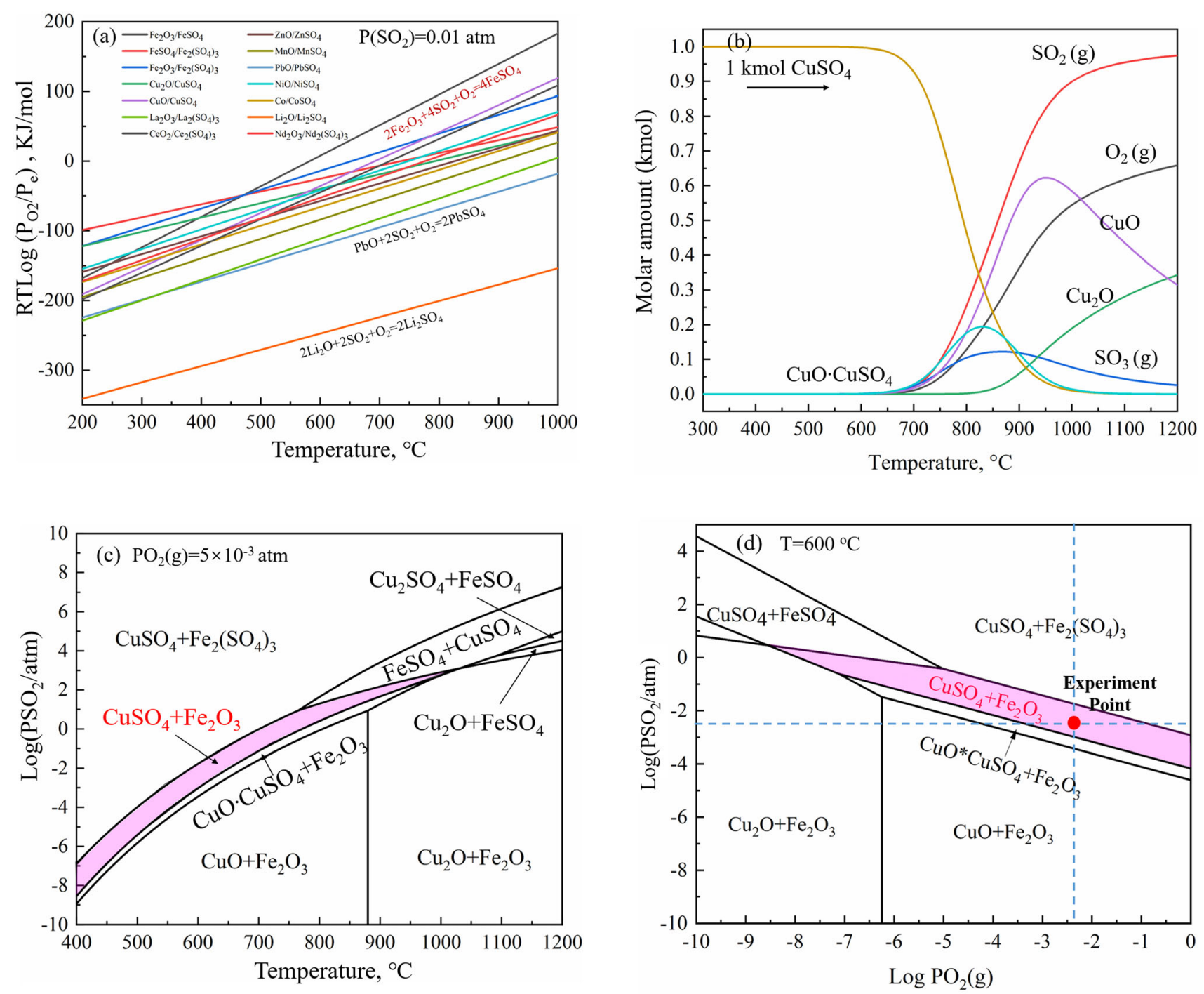

Fig. 2. (a) Ellingham diagram of some valuable metals at a fixed $\mathrm{SO}_{2}$ (g) of 0.01 atm, (b) composition for CuSO $\mathrm{C}_{4}$ thermal decomposition, (c) predominance area diagram obtained by superimposing the $\mathrm{Cu}-\mathrm{S}-\mathrm{O}$ and $\mathrm{Fe}-\mathrm{S}-\mathrm{O}$ diagrams at a fixed $\mathrm{O}_{2}(\mathrm{~g})$ partial pressure of 0.005 atm, and (d) predominance area diagram obtained by superimposing the Cu-S-O and Fe-S-O diagrams at $600^{\circ} \mathrm{C}$. Calculated using the HSC Chemistry 9.0 software package. ${ }^{41}$ 
generates a higher oxygen potential and the reaction occurs at lower temperatures than the others. High technology metals, like the REEs (rare earth elements, e.g., La, Ce, $\mathrm{Nd}$ ) and some battery metals (Zn, Mn, Li), can also be converted to water-soluble sulfates and separated from iron and other metals in given conditions. However, considering the mass content in the chosen materials, copper and iron were selected to verify the feasibility of the method in an atmosphere designed for their recovery.

Figure $2 \mathrm{~b}$ shows the thermal decomposition diagram of $\mathrm{CuSO}_{4}$ in an inert atmosphere. The decomposition reactions of copper sulfate take place at around $600^{\circ} \mathrm{C}$. The combined predominance area diagrams for $\mathrm{Cu}-\mathrm{S}-\mathrm{O}$ and $\mathrm{Fe}-\mathrm{S}-\mathrm{O}$ systems at a fixed oxygen potential $\left(P_{\mathrm{O} 2}=0.005 \mathrm{~atm}\right)$ were calculated in HSC Chemistry $9.0^{41}$ and are shown in Fig. 2c. In the diagram, the double oxides of copper and iron have been omitted. Considering the decomposition phenomena and energy-saving aspect, as well as some previous roasting studies, ${ }^{8,33} 600^{\circ} \mathrm{C}$ was selected as the set temperature for the experiments.

The isothermal predominance area diagrams for the $\mathrm{Cu}-\mathrm{S}-\mathrm{O}$ and $\mathrm{Fe}-\mathrm{S}-\mathrm{O}$ systems at $600^{\circ} \mathrm{C}$ were superimposed and are shown in Fig. 2d. The shaded composition range was the target atmosphere of this study for separating copper and iron. The formation of $\mathrm{Cu}-\mathrm{Fe}$ double oxides has been omitted. In this way, the experimental conditions were scouted for the experiments by means of thermodynamic calculations.

\section{RESULTS}

Chalcopyritic copper concentrate, smelting slag, and $\mathrm{CuO}, \mathrm{CuS}$, and $\mathrm{Fe}_{2} \mathrm{O}_{3}$ powders were roasted separately in the designed atmosphere at $600^{\circ} \mathrm{C}$ to study the reaction tendencies and mechanisms for different copper-bearing materials. This roasting method proved to be a feasible way to recycle copper when combined with water-leaching.

\section{Sulfation Roasting Behavior of Chalcopyrite}

The microstructures of roasted chalcopyrite at $8 \mathrm{~h}$ and $24 \mathrm{~h}$ in an $\mathrm{SO}_{2}-\mathrm{O}_{2}$ - $\mathrm{Ar}$ atmosphere are shown in Fig. 3. According to the microstructure and phase composition results, the reactions of chalcopyrite roasting were still in progress at $8 \mathrm{~h}$. A cuprous sulfide core was found at that time, whereas the formation of an oxidized crust $\left(\mathrm{CuO}\right.$ and $\left.\mathrm{Fe}_{2} \mathrm{O}_{3}\right)$ was not complete. Copper sulfate was detected but its fraction was not dominant. The reactions proceeded further after $24 \mathrm{~h}$ of roasting. $\mathrm{CuSO}_{4}$ could be detected but not all of the regions had reached the equilibrium assemblage at that point. No cuprous sulfide could be detected in the sample shown in Fig. 3b. After $24 \mathrm{~h}$, regions B and C contained the equilibrium assemblage, with simultaneous copper sulfate and iron oxide coexisting. Region A was still in the progress of being formed, and a copper oxide core could be seen in the core of the particle.

\section{Sulfation-Roasting Behavior of Slag and Copper-Iron Compounds}

The microstructures and EDS analysis data of the roasted slag samples at $8 \mathrm{~h}$ and $24 \mathrm{~h}$ in the $\mathrm{SO}_{2}-\mathrm{O}_{2^{-}}$ $\mathrm{Ar}$ atmosphere are shown in Fig. 4. In the smelting process, the majority of the copper dissolved in the slag phase in the form of $\mathrm{Cu}_{2} \mathrm{O}$, while $\mathrm{Cu}_{2} \mathrm{~S}$ was present in the mechanically entrained matte dispersion, forming as always a significant fraction of the total copper content in industrial slags. ${ }^{42,43}$ From the EDS analyses, the copper in the slag mainly existed as cuprous sulfide after $8 \mathrm{~h}$ of roasting time. Even after 24 h of sulfation roasting,
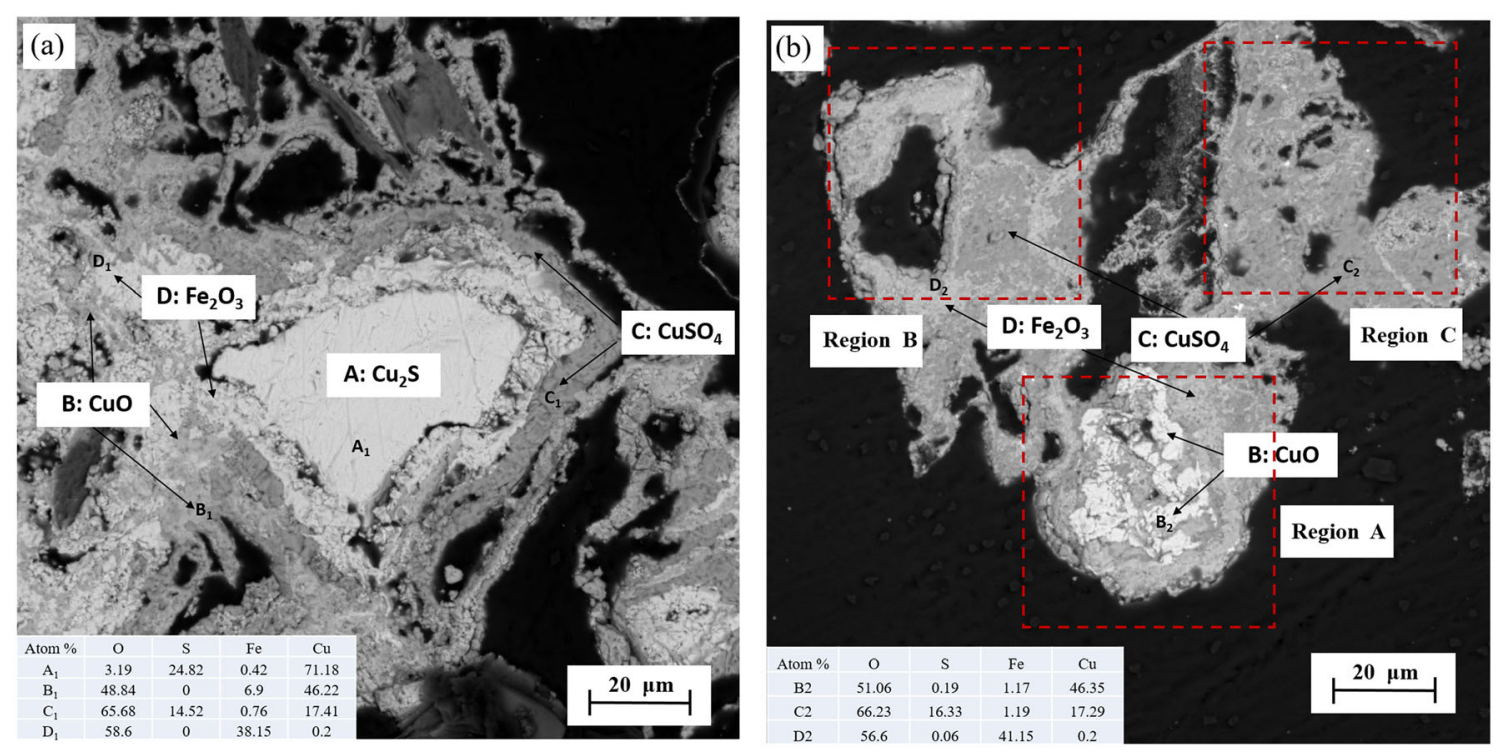

Fig. 3. Micrographs of roasted chalcopyrite samples after $8 \mathrm{~h}(\mathrm{a})$ and $24 \mathrm{~h}(\mathrm{~b})$ : (A) $\mathrm{Cu}_{2} \mathrm{~S},(\mathrm{~B}) \mathrm{CuO},(\mathrm{C}) \mathrm{CuSO}_{4}$, and (D) $\mathrm{Fe}_{2} \mathrm{O}_{3}$. 

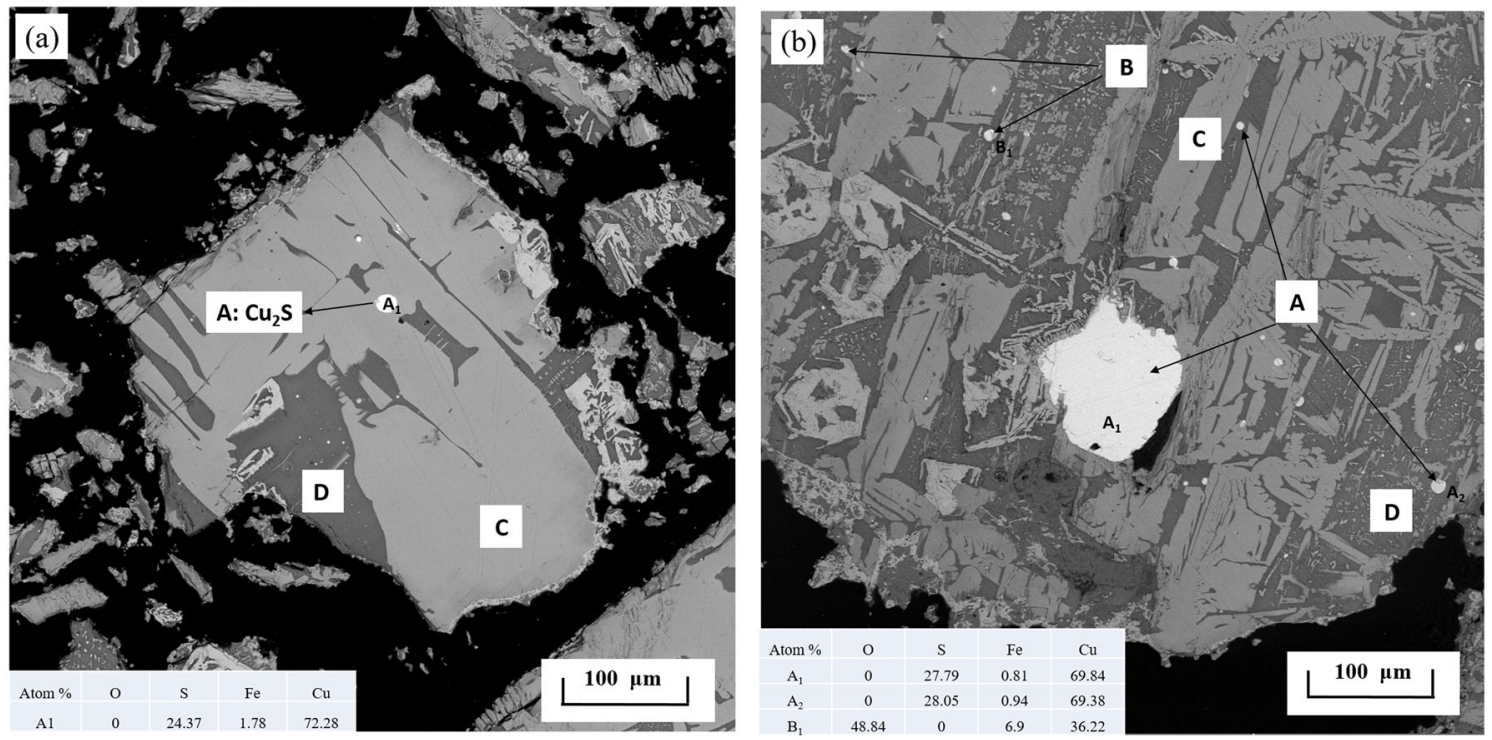

Fig. 4. Micrographs of roasted slag samples after $8 \mathrm{~h} \mathrm{(a)}$ and $24 \mathrm{~h}(\mathrm{~b}):(\mathrm{A}) \mathrm{Cu}_{2} \mathrm{~S},(\mathrm{~B}) \mathrm{CuO},(\mathrm{C})$ fayalite, and (D) intergranular glassy phase.
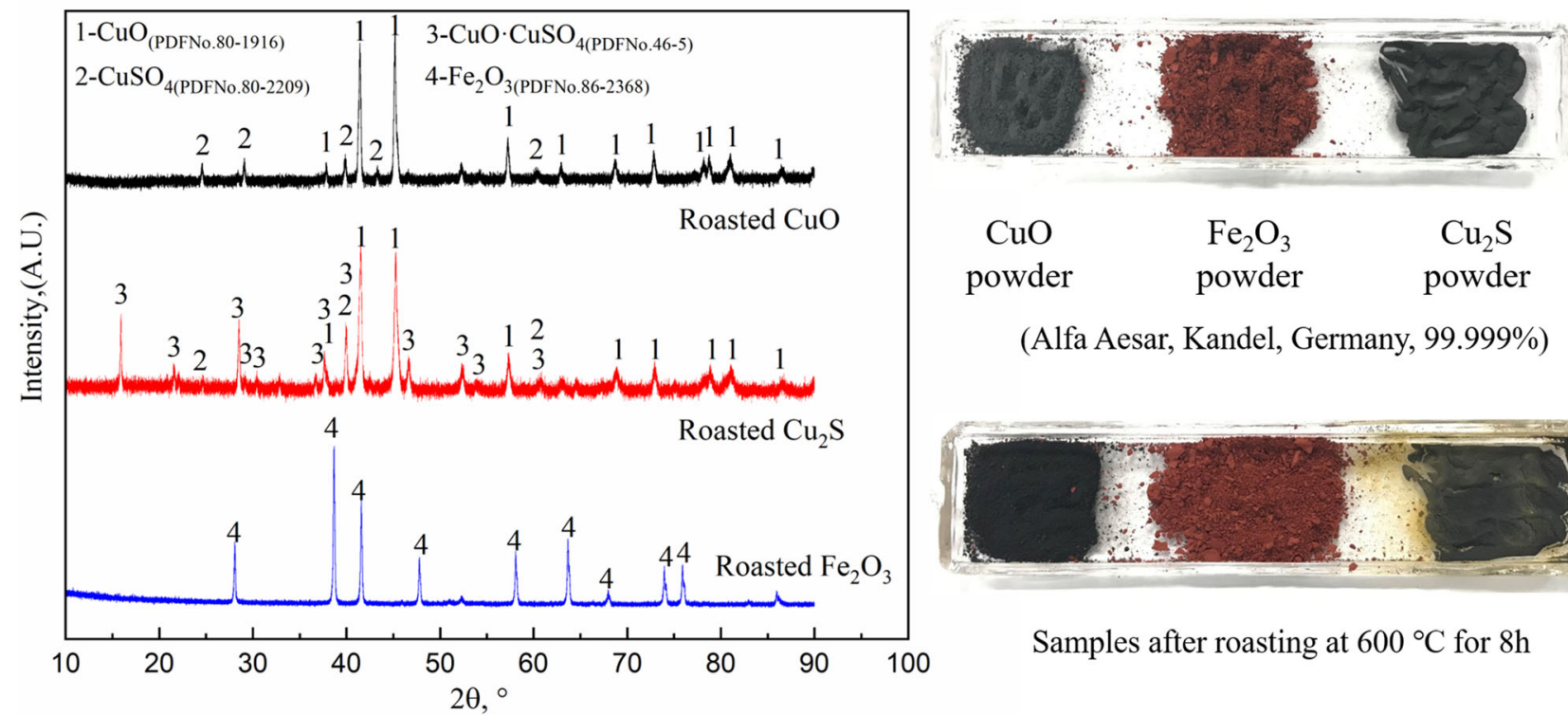

(Alfa Aesar, Kandel, Germany, 99.999\%)

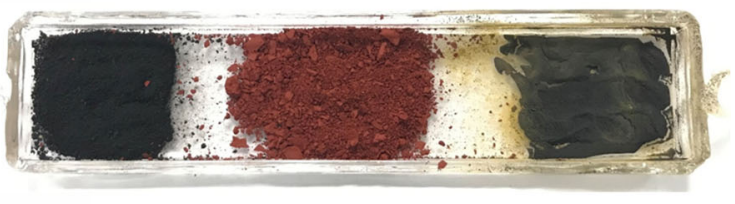

Samples after roasting at $600{ }^{\circ} \mathrm{C}$ for $8 \mathrm{~h}$

Fig. 5. XRD pattern and macrostructure characteristics for pure $\mathrm{Cu}_{2} \mathrm{~S}, \mathrm{CuO}$ and $\mathrm{Fe}_{2} \mathrm{O}_{3}$ powders after $8 \mathrm{~h}$ of sulfation roasting. (1) CuO, (2) $\mathrm{CuSO}_{4}$, (3) $\mathrm{CuO} \cdot \mathrm{CuSO}_{4}$, and (4) $\mathrm{Fe}_{2} \mathrm{O}_{3}$.

the droplets still retained in the slag were mainly cuprous sulfide. However, copper oxide particles were also detected, proving that copper reactions occur in the slag between $8 \mathrm{~h}$ and $24 \mathrm{~h}$ of roasting. No copper sulfate was found in the 8-h nor in the 24$\mathrm{h}$ roasted slags. According to the predominance area diagram in Fig. 2c, cuprous sulfide and copper oxide should have been converted to copper sulfate in the designed atmosphere.

To verify this assumption, pure $\mathrm{Cu}_{2} \mathrm{~S}, \mathrm{CuO}$, and $\mathrm{Fe}_{2} \mathrm{O}_{3}$ powders were sulfation roasted for $8 \mathrm{~h}$; the results are shown in Fig. 5. Based on the XRD analysis results, the $\mathrm{CuO}$ powder partly converted to the $\mathrm{CuSO}_{4}$ phase. In the case of the $\mathrm{Cu}_{2} \mathrm{~S}$ powder, $\mathrm{CuO}, \mathrm{CuSO}_{4}$, and $\mathrm{CuO} \cdot \mathrm{CuSO}_{4}$ were detected in the end product. However, no reactions occurred for $\mathrm{Fe}_{2} \mathrm{O}_{3}$, which agrees with the expected results. These experiments prove the recovery possibilities for the cuprous sulfide and copper oxide in slag under the experimental conditions. The reason that no copper sulfate was found in the copper slag after $8 \mathrm{~h}$ and $24 \mathrm{~h}$ of roasting can be regarded as the limitation of mass transfer in the iron silicate slag. In the chalcopyritic concentrate roasting experiments, cuprous sulfide converted to the copper oxide phase after only $8 \mathrm{~h}$ of roasting. Therefore, it can be concluded that, with a longer roasting time, the copper in the slag would be able to form copper sulfate and the detected copper oxide would exist as an intermediate product during the process. In that 
case, considering the slow reaction rate and the influence of fayalite slag on the mass transfer of $\mathrm{O}_{2}$ and $\mathrm{SO}_{2}$, sulfation roasting for recycling copper from slag, although possible, is probably not feasible.

\section{Reaction Mechanism of Chalcopyrite and Slag Sulfation Roasting}

Based on the analytical results of the end products and discussion of thermodynamic equilibria, it can be concluded that the sulfation roasting of a chalcopyritic copper concentrate under $0.5 \% \mathrm{SO}_{2}-$ $0.5 \% \mathrm{O}_{2}-99 \% \mathrm{Ar}$ mixture at $600^{\circ} \mathrm{C}$ takes place in three stages.

According to the standard Gibbs energy $\left(\Delta G^{\theta}\right.$, $\left.\mathrm{kJ} \mathrm{mol}^{-1}\right)$ of reaction versus temperature $\left(T,{ }^{\circ} \mathrm{C}\right)$ relationship calculated with HSC Chemistry $9.0,{ }^{41}$ shown in Fig. 6, chalcopyrite would not decompose to component sulfides by reaction (1) at $600^{\circ} \mathrm{C}$. During roasting, the first step (stage 1) was the initial oxidation of the chalcopyrite particle to $\mathrm{FeS}$ and $\mathrm{Cu}_{2} \mathrm{~S}$ by reaction (2), and $\mathrm{FeS}$ was further oxidized to $\mathrm{Fe}_{2} \mathrm{O}_{3}$ by reaction (3). $\mathrm{Cu}_{2} \mathrm{~S}$ oxidation initiated later, as in the microstructure shown in Fig. $4 \mathrm{a}$, after $8 \mathrm{~h}$ of sulfation roasting. These products could be detected simultaneously in reaction stage 1.

$$
5 \mathrm{CuFeS}_{2}=\mathrm{Cu}_{5} \mathrm{FeS}_{4}+4 \mathrm{FeS}+2 \mathrm{~S}
$$

$$
\begin{gathered}
\Delta G^{\theta}\left(\mathrm{kJ} \cdot \mathrm{mol}^{-1}\right)=-0.1807 T\left({ }^{\circ} \mathrm{C}\right)+178.96 \\
2 \mathrm{CuFeS}_{2}+\mathrm{O}_{2}(\mathrm{~g})=\mathrm{Cu}_{2} \mathrm{~S}+2 \mathrm{FeS}+\mathrm{SO}_{2}(\mathrm{~g}) \\
\Delta G^{\theta}\left(\mathrm{kJ} \cdot \mathrm{mol}^{-1}\right)=-0.067 T\left({ }^{\circ} \mathrm{C}\right)-201.95 \\
2 \mathrm{FeS}+3.5 \mathrm{O}_{2}(\mathrm{~g})=\mathrm{Fe}_{2} \mathrm{O}_{3}+2 \mathrm{SO}_{2}(\mathrm{~g}) \\
\Delta G^{\theta}\left(\mathrm{kJ} \cdot \mathrm{mol}^{-1}\right)=0.302 T\left({ }^{\circ} \mathrm{C}\right)-1150.21
\end{gathered}
$$

Further oxidation reactions took place in stage 2. In the atmosphere used, more oxygen was transferred to the particles from the surrounding gas, and the following oxidation reactions took place:
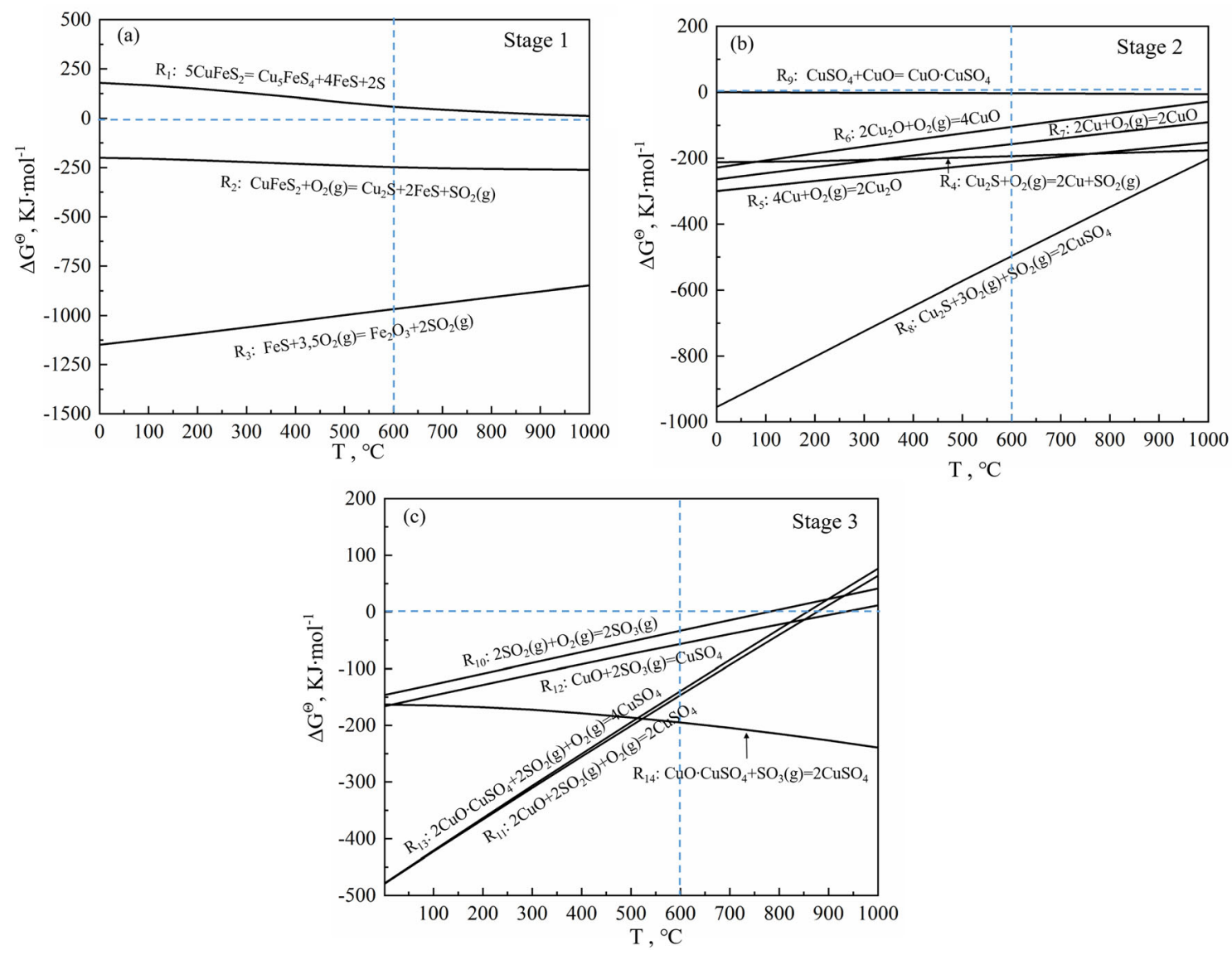

Fig. 6. Relationships between $\Delta G^{\theta}$ (kJ mol$\left.{ }^{-1}\right)$ and temperature $\left({ }^{\circ} \mathrm{C}\right)$ for the sulfation-roasting reactions (stages 1-3, reactions (1)-(14)). (a) reactions (1)-(3), (b) reactions (4)-(9), and (c) reactions (10)-(14). 
$\mathrm{Cu}_{2} \mathrm{~S}$ was further oxidized and reacted into different forms of copper $\left(\mathrm{Cu}, \mathrm{Cu}_{2} \mathrm{O}, \mathrm{CuO}\right)$ through reactions (4)-(7) or converted directly to $\mathrm{CuSO}_{4}$, in one step through reaction (8). $\mathrm{CuSO}_{4}$ from reaction (8) would react with $\mathrm{CuO}$ to $\mathrm{CuO} \cdot \mathrm{CuSO}_{4}$ through reaction (9), depending on the local $\mathrm{p}\left(\mathrm{O}_{2}\right)$ and $\mathrm{p}\left(\mathrm{SO}_{2}\right)$. For the $\mathrm{Cu}_{2} \mathrm{~S}$ in the slag, with the fayalite slag as a barrier to mass transfer, the $\mathrm{Cu}_{2} \mathrm{~S}$ oxidation reactions would happen slowly. This may explain the experimental observation that the $\mathrm{Cu}_{2} \mathrm{~S}$ in the slag was still present after $24 \mathrm{~h}$ of roasting (see Fig. $4 \mathrm{~b}$ ).

$$
\begin{gathered}
\mathrm{Cu}_{2} \mathrm{~S}+\mathrm{O}_{2}(\mathrm{~g})=2 \mathrm{Cu}+\mathrm{SO}_{2}(\mathrm{~g}) \\
\Delta \mathrm{G}^{\theta}\left(\mathrm{kJ} \cdot \mathrm{mol}^{-1}\right)=0.0377 T\left({ }^{\circ} \mathrm{C}\right)-215.11 \\
4 \mathrm{Cu}^{+} \mathrm{O}_{2}(\mathrm{~g})=2 \mathrm{Cu}_{2} \mathrm{O} \\
\Delta G^{\theta}\left(\mathrm{kJ} \cdot \mathrm{mol}^{-1}\right)=0.1474 T\left({ }^{\circ} \mathrm{C}\right)-298.72 \\
\Delta G^{\theta}\left(\mathrm{kJ} \cdot \mathrm{mol}^{-1}\right)=0.7544 T\left({ }^{\circ} \mathrm{C}\right)-952.47 \\
2 \mathrm{Cu}_{2} \mathrm{O}+\mathrm{O}_{2}(\mathrm{~g})=4 \mathrm{CuO} \\
G^{\theta}\left(\mathrm{kJ} \cdot \mathrm{mol}^{-1}\right)=0.1735 T\left({ }^{\circ} \mathrm{C}\right)-262.15 \\
\mathrm{CuSO}_{4}+\mathrm{CuO}+3 \mathrm{C}_{2}(\mathrm{~g})+\mathrm{SO} \cdot \mathrm{CuSO} 4 \\
\Delta G^{\theta}\left(\mathrm{kJ} \cdot \mathrm{mol}^{-1}\right)=0.1996 T\left({ }^{\circ} \mathrm{C}\right)-225.58 \\
2 \mathrm{Cu}^{-1}+\mathrm{O}_{2}(\mathrm{~g})=2 \mathrm{CuO}
\end{gathered}
$$

$$
\Delta G^{\theta}\left(\mathrm{kJ} \cdot \mathrm{mol}^{-1}\right)=0.0772 T\left({ }^{\circ} \mathrm{C}\right)-153.45
$$

For the smelting slag, the composition is more complex. The copper content in the slag is limited, and the major constituents are iron, silica, alumina, and calcium oxide, as well as some trace elements. 


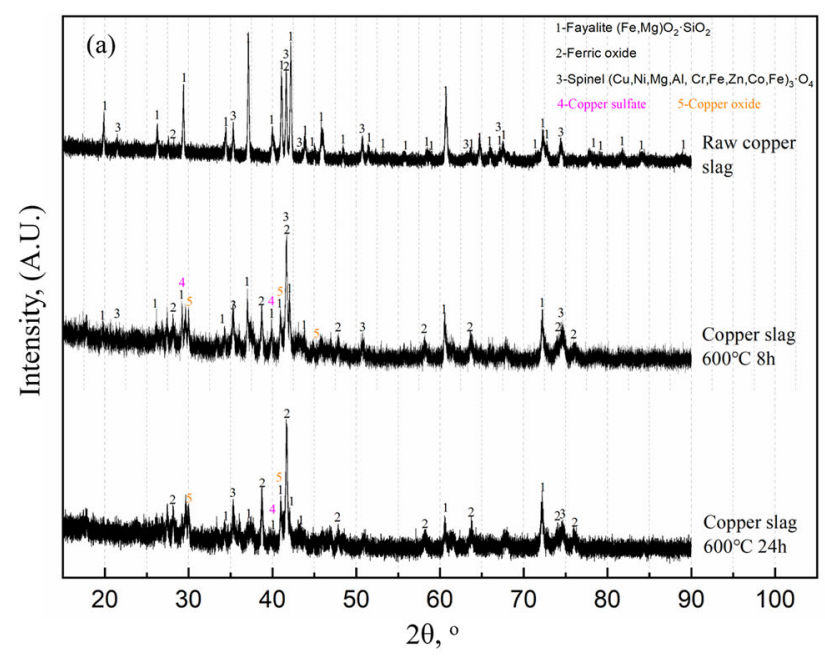

(b)
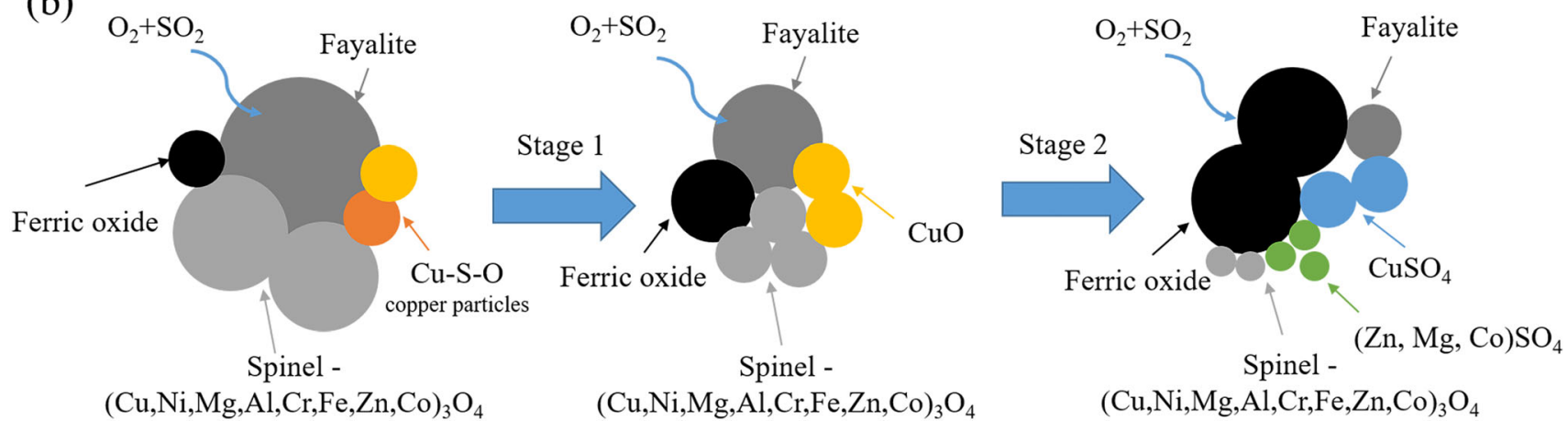

Fig. 7. XRD patterns for selected slag samples (a) and the slag sulfation-roasting mechanism (b).

However, due to the huge amount of slag in industrial production processes, copper recovery from industrial slag has attracted a great deal of attention. During the copper-smelting process, the majority of copper dissolves in the slag phase by two mechanisms: sulfidic mechanical inclusion loss and oxidic dissolution loss. ${ }^{42}$

The XRD pattern of the raw slag and roasted slag samples at $8 \mathrm{~h}$ and $24 \mathrm{~h}$ in the $\mathrm{SO}_{2}-\mathrm{O}_{2}$-Ar atmosphere are shown in Fig. 7a. From the XRD analysis results, copper and other metals like $\mathrm{Ni}, \mathrm{Mg}, \mathrm{Al}$, and $\mathrm{Zn}$ dissolved in the spinel phase in the slag in the form of $(\mathrm{Cu}, \mathrm{Ni}, \mathrm{Mg}, \mathrm{Al}, \mathrm{Cr}, \mathrm{Fe}, \mathrm{Zn}, \mathrm{Co}, \mathrm{Fe})_{3} \cdot \mathrm{O}_{4}$. During the sulfation-roasting process, the intensity of the fayalite and spinel phases in the XRD pattern decreased with the prolonging of the sulfation-roasting time, while the ferric oxide phase intensity dominated in the slag after $24 \mathrm{~h}$ of sulfation roasting. After $8 \mathrm{~h}$ of roasting, the copper sulfate and copper oxide phase could be detected in the XRD pattern.

Combining this with the micrograph results in Fig. 4, the copper dissolved in the fayalite phase converted from $\mathrm{Cu}_{2} \mathrm{~S}(8 \mathrm{~h})$ to $\mathrm{CuO}(24 \mathrm{~h})$, which indicated the progress of reactions (4)-(7). For the pure $\mathrm{Cu}_{2} \mathrm{~S}$ and $\mathrm{CuO}$ powders, $\mathrm{CuSO}_{4}$ was detected after sulfation roasting in this experiment, verifying the advancement of reactions (8)-(14). Thus, the reaction mechanism of slag sulfation roasting for recovering copper can be explained as shown in Fig. 7b. The copper dissolved in the slag in sulfide and oxide forms, surrounded by fayalite as well as spinel crystals and an intergranular glassy phase. During the sulfation-roasting process, the copper in the slag also followed the reaction pattern of chalcopyrite sulfation roasting. Reactions (4)-(14) took place in the slag during this process. At the same time, fayalite tended to convert to ferric oxide and the spinel phase structure was destroyed, so that more metals were released from the spinel phase, facilitating their sulfation and recycling.

Besides the $\mathrm{Cu}-\mathrm{Fe}-\mathrm{S}-\mathrm{O}$ components of the chalcopyrite, the slag contains minority and trace metals such as $\mathrm{Zn}, \mathrm{Mg}$, Co, etc., and thus is a more complex system. From the thermodynamic calculations shown in Fig. 2a, we can predict that different metals can be effectively separated from iron by choosing a suitable temperature and atmosphere for sulfation roasting. From the analytical results of the 
slag, the sulfation-roasting method can reduce the fraction of the fayalite phase and break the spinel structure of the magnetite. In that case, more metals will be released for sulfation, which can be a potential method for dealing with complex ores and secondary materials like slag and even copper slag flotation tailings.

\section{CONCLUSION}

The sulfation-roasting technique is an effective low-temperature pyrometallurgical pretreatment for the recycling of various complex multi-metal ores and copper-bearing waste materials and residues. With the sulfation-roasting process, strong sulfate formers, like $\mathrm{Co}, \mathrm{Li}, \mathrm{Ni}$ and the rare earths, existing at low concentrations can be separated completely from an iron-rich and silicate matrix. We confirmed its feasibility with coexisting copper sulfate and iron(III) oxide when roasting chalcopyritic copper concentrate and a copper smelting slag, as well as pure copper and iron sulfide/oxide powders in an $0.5 \% \mathrm{~S} \mathrm{O}_{2}-0.5 \% \mathrm{O}_{2}-99 \% \mathrm{Ar}$ atmosphere at $600^{\circ} \mathrm{C}$. The results of the present work are important for pretreating copper-bearing materials in a feasible way, as a step in the sustainable recovery of metals from various waste streams and also for treating copper-smelting slags.

\section{ACKNOWLEDGEMENTS}

Open access funding provided by Aalto University. The authors would like to acknowledge the financial support from the China Scholarship Council. Thanks are also due to Aalto University and Boliden Harjavalta (Finland) for their contributions. This study utilized the Academy of Finland's RawMatTERS Finland Infrastructure (RAMI) based jointly at Aalto University, GTK, and VTT in Espoo.

\section{FUNDING}

The study received financial support from Aalto University.

\section{DISCLOSURE}

The authors report no conflicts of interest and the authors alone are responsible for the content and writing of the article.

\section{OPEN ACCESS}

This article is licensed under a Creative Commons Attribution 4.0 International License, which permits use, sharing, adaptation, distribution and reproduction in any medium or format, as long as you give appropriate credit to the original author(s) and the source, provide a link to the Creative Commons licence, and indicate if changes were made. The images or other third party material in this article are included in the article's Creative Commons licence, unless indicated otherwise in a credit line to the material. If material is not included in the article's Creative Commons licence and your intended use is not permitted by statutory regulation or exceeds the permitted use, you will need to obtain permission directly from the copyright holder. To view a copy of this licence, visit $h$ ttp://creativecommons.org/licenses/by/4.0/.

\section{REFERENCES}

1. W.G. Davenport and E. Partelpoeg, Flash smelting: analysis, control and optimization, 1st ed. (Exeter: Wheaton, 1987), pp. 1-10.

2. I. Bellemans, E. De Wilde, N. Moelans, and K. Verbeken, Adv. Colloid Interface Sci. 255, 7 (2018).

3. B. Gorai and R. Jana, Conserv. Recycl. 39, 299 (2003).

4. J. Cui and L. Zhang, J. Hazard. Mater. 158, 228 (2008).

5. M. Shuva, M. Rhamdhani, G. Brooks, S. Masood, and M. Reuter, J. Cleaner Prod. 131, 795 (2016).

6. R. Moskalyk and A. Alfantazi, Miner. Eng. 16, 893 (2003).

7. J. Paynter, J. South Afr. Inst. Min. Metall. 74, 158 (1973).

8. M. Ozer, E. Acma, and G. Atesok, Asia-Pac. J. Chem. Eng. (2017). https://doi.org/10.1002/apj.2078.

9. N. Pradhan, K. Nathsarma, K.S. Rao, L. Sukla, and B. Mishra, Miner. Eng. 21, 355 (2008).

10. Z.A. Sarı, M.D. Turan, H. Nizamoğlu, A. Demiraslan, and T. Depci, Soc. Min., Metall., Explor., Trans.; (2020). https://doi. org/10.1007/s42461-020-00196-8.

11. M.D. Turan, H. Arslanoğlu, and H.S. Altundoğan, J. Taiwan Inst. Chem. Eng. 50, 49 (2015).

12. M.D. Turan and H.S. Altundoğan, Int. J. Miner., Metall. Mater (2014). https://doi.org/10.1007/s12613-014-0982-x.

13. E. Córdoba, J. Muñoz, M. Blázquez, F. González, and A. Ballester, Hydrometallurgy 93, 81 (2008).

14. E. Córdoba, J. Muñoz, M. Blázquez, F. González, and A. Ballester, Hydrometallurgy 93, 88 (2008).

15. C. Peng, F. Liu, Z. Wang, B.P. Wilson, and M. Lundström, J. Power Sources 415, 179 (2019).

16. J. Shi, C. Peng, M. Chen, Y. Li, H. Eric, L. Klemettinen, M. Lundström, P. Taskinen, and A. Jokilaakso, JOM 71, 4473 (2019).

17. J. Hu, J. Zhang, H. Li, Y. Chen, and C. Wang, J. Power Sources 351, 192 (2017).

18. T. Träger, B. Friedrich, and R. Weyhe, Chem. Ing. Tech. (2015). https://doi.org/10.1002/cite.201500066.

19. Y.-X. Zheng, W. Liu, W.-Q. Qin, J.-W. Han, K. Yang, H.-L. Luo, and D.-W. Wang, Can. Metall. Q. 54, 92 (2015).

20. X.-S. Li and B. Xie, Int. J. Miner., Metall. Mater (2012). h ttps://doi.org/10.1007/s12613-012-0600-8.

21. T. Ingraham and R. Kerby, Can. Metall. Q. 6, 89 (1967).

22. M. Rabah, Hydrometallurgy 47, 281 (1998).

23. S. Prasad and B. Pandey, J. Therm. Anal. Calorim. 58, 625 (1999)

24. M. Sokić, I. Ilić, D. Živković, and N. Vučković, Metalurgija (Belgrade, Serb.). 47, 109 (2008).

25. L. Sargsyan and A. Hovhannisyan, Metall. Min. Ind. 2, 225 (2010).

26. H. Kellogg, Trans. Metall. Soc. AIME. 230, 1622 (1964).

27. A. Yazawa, Can. Metall. Q. 3, 443 (1974).

28. T. Rosenqvist, Metall. Trans. B 3, 337 (1978).

29. R. Souza, C. Queiroz, J. Brant, and E. Brocchi, Miner. Eng. 130, 156 (2019).

30. J. Yianatos and V. Antonucci, Miner. Eng. 14, 1411 (2001).

31. F. Tümen and N.T. Bailey, Hydrometallurgy 25, 317 (1990).

32. R.K. Nadirov, Trans. Indian Inst. Met. 72,603 (2019).

33. A. Wiessner, U. Kappelmeyer, P. Kuschk, and M. Kästner, Water Res. 39, 4643 (2005).

34. M. Runkel and P. Sturm, J. South Afr. Inst. Min. Metall. 109, 491 (2009).

35. S. Prasad and B. Pandey, Miner. Eng. 11, 763 (1998)

36. S. Prasad and B. Pandey, Can. Metall. Q. 38, 237 (1999).

37. M.D. Dimitrijevic, D.M. Urosevic, Z.D. Jankovic, and S.M. Milic, Physicochem. Probl. Miner. Process. 52, 409 (2016). 
38. M.A. Topcu, A. Rüșen, and B. Derin, J. Mater. Res. Technol. 8, 6244 (2019).

39. K. Jacob, R. Akila, and A. Shukla, J. Solid State Chem. 69, 109 (1987).

40. C.A. Pickles and O. Marzoughi, Minerals. (2019). https://doi. org/10.3390/min 9010018.

41. A. Roine, HSC Chemistry for Windows, v. 9.2.6 (Pori, Finland: Outotec Research, 2019). www.hsc-chemistry.com. Accessed 25 June 2019.
42. K. Genevski and V. Stefanova, Can. Metall. Q. 47, 51 (2008),

43. X. Wan, L. Shen, A. Jokilaakso, H. Eriç, and P. Taskinen, Miner. Process. Extr. Metall. Rev. 11, 1 (2020).

Publisher's Note Springer Nature remains neutral with regard to jurisdictional claims in published maps and institutional affiliations. 